\title{
Comparison of yeast extract prepared by autolysis or steam explosion as a cheap nutrient supplement for very high gravity ethanol fermentation of cassava starch
}

\author{
Thanaporn Palasak ${ }^{\mathrm{a}}$, Sarintip Sooksai ${ }^{\mathrm{b}}$, Ancharida Savarajara ${ }^{\mathrm{c}, *}$ \\ a Biotechnology Program, Faculty of Science, Chulalongkorn University, Bangkok 10330 Thailand \\ b The Institute of Biotechnology and Genetic Engineering, Chulalongkorn University, \\ Bangkok 10330 Thailand \\ c Department of Microbiology, Faculty of Science, Chulalongkorn University, Bangkok 10330 Thailand
}

*Corresponding author, e-mail: sanchari@chula.ac.th

Received 23 Mar 2018

Accepted 27 Feb 2019

\begin{abstract}
Very high gravity fermentation of saccharified cassava starch containing $280 \mathrm{~g} / \mathrm{l}$ reducing sugar to ethanol by the osmotolerant Saccharomyces cerevisiae G2-3-2 strain required supplementation with inorganic nutrients $\left(\mathrm{KH}_{2} \mathrm{PO}_{4}\right.$, $\left(\mathrm{NH}_{4}\right)_{2} \mathrm{HPO}_{4}$, and $\mathrm{MgSO}_{4} \cdot 7 \mathrm{H}_{2} \mathrm{O}$ and yeast extract (YE) to maximize the ethanol production level and rate. Comparison of the YE prepared by the autolysis of spent brewer's yeast at either $50^{\circ} \mathrm{C}$ for $24 \mathrm{~h}$ (A-YE) or steam explosion at $200{ }^{\circ} \mathrm{C}$ for $20 \mathrm{~min}$ (SE-YE), as a replacement for commercial yeast extract (C-YE) at $7.5 \mathrm{~g} / 1$, revealed that A-YE gave a slightly higher ethanol concentration $(113.85 \mathrm{~g} / \mathrm{l})$ than the SE-YE $(107.81 \mathrm{~g} / \mathrm{l})$, and was comparable to that obtained with the C-YE (113.14 g/l). At the optimal concentration of A-YE supplementation $(5.23 \mathrm{~g} / \mathrm{l})$, the ethanol concentration in the ferment reached $115.77 \mathrm{~g} / \mathrm{l}$ at $24 \mathrm{~h}$, an ethanol productivity of $4.82 \mathrm{~g} / \mathrm{l} / \mathrm{h}$.
\end{abstract}

KEYWORDS: Saccharomyces cerevisiae, osmotolerant, spent brewer's yeast

\section{INTRODUCTION}

Bioethanol is a promising alternative energy that is renewable and relatively environment-friendly, where several starch crops, such as corn, wheat and cassava, have already been commercially exploited for bioethanol production in several countries ${ }^{1}$. A higher starch yield per hectare and all year availability due to flexibility in planting and harvesting of cassava are its major advantages over other crops. Cassava chip is one of the two main raw materials for ethanol production in Thailand. However, as prepared it is mostly mixed with sand and stone, causing mechanical damage to production equipment. Although the price of cassava starch is higher than cassava chip, the cost of the two raw materials are comparatively on the same level when considering the maintenance and repair expenditures of the production equipment due to the wear and tear caused by sand and stone from cassava chips.

To increase the productivity and cost effectiveness of bioethanol production, many process improvements, including very high gravity (VHG) technology, have been studied. Overall, VHG is defined as the preparation and fermentation to completion of a solution containing more than $270 \mathrm{~g} / 1$ total sugar ${ }^{2}$. Ethanolic fermentation from a very high sugar concentration has many advantages from an industrial point of view, resulting in reduced costs because of the lower energy consumption ${ }^{3}$.

However, these fermentations are rarely fast and complete due to the induced physiological changes in the fermenting microbial cells. The high sugar concentration in the fermentation media causes an increased osmotic pressure that has a damaging effect on yeast cells and leads to an increased level of cell lysis and reduced viability, and so a decreased ethanol production ${ }^{4}$. Nevertheless, these effects can be relieved to some extent by supplementation of the media with appropriate nutrients ${ }^{1,5,6}$.

Saccharomyces cerevisiae can ferment a higher concentration of sugar when all the required nutrients are provided in sufficient amounts ${ }^{7}$. Several investigators have observed that yeast extract (YE), ammonium ions, urea, and calcium and magnesium ions have protective effects on either the growth 
and fermentation or the viability of $S$. cerevisiae, and so stimulate the fermentation rate and ethanol production $^{1}$.

Recently we isolated a high ethanol producingosmotolerant $S$. cerevisiae strain (G2-3-2) and determined its optimized ethanol production medium (oEPM), in terms of maximal ethanol production rate, as; glucose $280 \mathrm{~g} / \mathrm{l}$, Bacto-peptone $5 \mathrm{~g} / \mathrm{l}$, YE $7.5 \mathrm{~g} / \mathrm{l},\left(\mathrm{NH}_{4}\right)_{2} \mathrm{HPO}_{4} 1 \mathrm{~g} / \mathrm{l}, \mathrm{MgSO}_{4} \cdot 7 \mathrm{H}_{2} \mathrm{O} 1.5 \mathrm{~g} / \mathrm{l}$, $\mathrm{KH}_{2} \mathrm{PO}_{4} 3 \mathrm{~g} / \mathrm{l}, \mathrm{CaCl}_{2} \cdot 2 \mathrm{H}_{2} \mathrm{O} 1 \mathrm{~g} / \mathrm{l}, \mathrm{MnSO}_{4} \cdot 4 \mathrm{H}_{2} \mathrm{O}$ $0.5 \mathrm{~g} / \mathrm{l}, \mathrm{ZnSO}_{4} \cdot 7 \mathrm{H}_{2} \mathrm{O} 0.2 \mathrm{~g} / \mathrm{l}, \mathrm{pH} 5.0^{8}$. To produce ethanol from saccharified cassava starch (SCS) by VHG technology using $S$. cerevisiae G2-3-2 on industrial scale, the required nutrient supplementation had to be reinvestigated. The SCS is composed of not only fermentable sugars but also some level of nitrogen, and major and minor trace elements required for the growth and ethanol fermentation of $S$. cerevisiae. Furthermore, YE and peptone are not economically viable supplements in industrial fermentation due to their high cost.

In this study, the required nutrient supplementation for the VHG ethanol fermentation of SCS was investigated. As a cheap and readily available source, YE was prepared from spent brewer's yeast, a rich source of amino acids, vitamins, minerals and fatty acids for promoting the growth of yeast and ethanol fermentation ${ }^{4}$, by cell autolysis (A-YE) and steam explosion (SE-YE) to compare the effect of intracellular lysate and whole cell decomposition, respectively, on the improvement of VHG ethanol production.

\section{MATERIALS AND METHODS}

\section{Cassava starch and enzymes}

Cassava starch, a product of E.T.C. International Trading Co., Ltd. (Nonthaburi, Thailand) under the Thai fish brand, was used in this study. The $\alpha$-amylase (Spezyme alpha; $13775 \mathrm{AAU} / \mathrm{g}$ ) and glucoamylase (GC 147; $580 \mathrm{TGAU} / \mathrm{g}$ ) (Genencor, Danisco US Inc., USA) used in this study were a gift from the Thai Alcohol Public Co., Ltd., Nakhonpathom, Thailand.

\section{Saccharification of cassava starch}

Cassava starch (15 g) was suspended in distilled water $(50 \mathrm{ml})$, adjusted to $\mathrm{pH} 5.8$ and then liquefied by $26.39 \mathrm{AAU} / \mathrm{g} \alpha$-amylase at $85^{\circ} \mathrm{C}$ for $3 \mathrm{~h}$. The resultant gelatinized starch solution was adjusted to $\mathrm{pH} 4.5$ and saccharified by $16.45 \mathrm{TGAU} / \mathrm{g}$ glucoamylase at $60^{\circ} \mathrm{C}$ for $30 \mathrm{~min}$. After clarification of the SCS solution by centrifugation $\left(7871 \mathrm{~g}, 4^{\circ} \mathrm{C}\right.$,
$10 \mathrm{~min}$ ) the resultant clear syrup was analysed for its reducing sugar content ${ }^{9}$, while inorganic nutrients and trace elements were analysed by Food Research and Testing Laboratory, Faculty of Science, Chulalongkorn University based on AOAC standard method ${ }^{10,11}$. The dose of $\alpha$-amylase and glucoamylase used in the above liquefaction and saccharification steps were selected from preliminary experiments (26.39-42.22 AAU/g and 4.1128.79 TGAU/g, respectively) designed to obtain a clear syrup containing $280 \mathrm{~g} / \mathrm{l}$ reducing sugar.

\section{Microorganism and inoculum preparation}

The osmotolerant $S$. cerevisiae G2-3-2 strain $^{8}$ was used in this study. A single colony grown on YPD agar (YE $3 \mathrm{~g} / \mathrm{l}$, Bacto-peptone $3 \mathrm{~g} / \mathrm{l}$, glucose $100 \mathrm{~g} / \mathrm{l}$, agar $20 \mathrm{~g} / \mathrm{l}, \mathrm{pH} 5.0$ ) at $30^{\circ} \mathrm{C}$ for $48 \mathrm{~h}$ was inoculated into $50 \mathrm{ml}$ of modified YM broth (YE $7.5 \mathrm{~g} / \mathrm{l}$, Bacto-peptone $5 \mathrm{~g} / \mathrm{l}$, malt extract $3 \mathrm{~g} / 1$ and glucose $150 \mathrm{~g} / \mathrm{l}, \mathrm{pH}$ 5.0) in a 250-ml Erlenmeyer flask and incubated at $30^{\circ} \mathrm{C}, 200 \mathrm{rpm}$ for $24 \mathrm{~h}$. The resultant culture was transferred into $50 \mathrm{ml}$ of modified YM broth in a $250 \mathrm{ml}$ Arm flask at an initial optical density at $660 \mathrm{~nm}$ of 0.05 and incubated at the same condition as above until it reached late log phase $(15 \mathrm{~h})$. The late log phase cells were then precipitated by centrifugation $\left(7871 \mathrm{~g}, 4^{\circ} \mathrm{C}, 15 \mathrm{~min}\right)$, resuspended and the cell density determined before use as the inoculum.

\section{Ethanol production medium}

The SCS medium (SCSM) composition was the same as the oEPM except for containing $280 \mathrm{~g} / 1$ glucose equivalent of SCS solution instead of glucose. Each medium was sterilized by autoclaving at $110^{\circ} \mathrm{C}$ for $10 \mathrm{~min}$.

\section{Ethanol production}

The inoculum was inoculated at an initial yeast cell number of $1 \times 10^{9}$ cells $/ \mathrm{ml}$ into $35 \mathrm{ml}$ of oEPM or SCSM in a 50-ml Erlenmeyer flask. The inoculated flask was incubated at $30^{\circ} \mathrm{C}$ under an oxygen limited condition for $72 \mathrm{~h}$ with shaking at $100 \mathrm{rpm}$ allowing $\mathrm{CO}_{2}$ release by capping the flask with a perforated rubber stopper connected to a U-shape glass tube containing a $\mathrm{CuSO}_{4}$-lock. Thus only the oxygen dissolved in the culture medium and in the air space (ca. $15 \mathrm{ml}$ ) above was available. Every $24 \mathrm{~h}$, the resultant cultures (three independent flasks) were then centrifuged $\left(7871 \mathrm{~g}, 4^{\circ} \mathrm{C}, 15 \mathrm{~min}\right)$ and the supernatants were analysed for the ethanol and reducing sugar contents. 
Table 1 Composition of the SCS media and their modification.

\begin{tabular}{|c|c|c|c|c|}
\hline \multirow[t]{2}{*}{ Medium No. } & \multirow{2}{*}{$\begin{array}{c}\text { Trace } \\
\text { element }^{\mathrm{a}}\end{array}$} & \multirow{2}{*}{$\begin{array}{l}\text { Inorganic } \\
\text { nutrient }^{\mathrm{b}}\end{array}$} & \multicolumn{2}{|c|}{ Complex nutrient } \\
\hline & & & $\mathrm{C}-\mathrm{YE}^{\mathrm{c}}$ & Peptone $^{\mathrm{d}}$ \\
\hline SCSM & + & + & + & + \\
\hline mSCSM 1 & - & + & + & + \\
\hline mSCSM 2 & - & - & + & + \\
\hline mSCSM 3 & - & + & - & - \\
\hline mSCSM 4 & - & - & - & - \\
\hline mSCSM 5 & - & + & + & - \\
\hline mSCSM 6 & - & + & - & + \\
\hline $\begin{array}{l}\text { a } \mathrm{CaCl}_{2} \cdot 2 \\
\text { and } \mathrm{ZnSO} \\
\mathrm{MgSO}_{4} \cdot 7 \\
\mathrm{~g} / \mathrm{l} ;{ }^{d} \text { pept }\end{array}$ & $\begin{array}{l}\mathrm{H}_{2} \mathrm{O} \quad 1 \\
\cdot 7 \mathrm{H}_{2} \mathrm{O} \\
\mathrm{I}_{2} \mathrm{O} 1.5 \mathrm{~g} \\
\text { ne } 5 \mathrm{~g} / \mathrm{l} ;\end{array}$ & $\begin{array}{l}\mathrm{g} / \mathrm{l}, \mathrm{MnS} \\
0.2 \mathrm{~g} / \mathrm{l} ; \mathrm{b} \\
1 \text {, and } \mathrm{KH}_{2} \\
\text { +, with; }- \text {, }\end{array}$ & $\begin{array}{l}{ }_{4} \cdot 4 \mathrm{H}_{2} \\
\left.\mathrm{NH}_{4}\right)_{2} \mathrm{I} \\
\mathrm{O}_{4} 3 \mathrm{~g} \\
\text { vithout. }\end{array}$ & $\begin{array}{cc}0.5 & \mathrm{~g} / \mathrm{l} \\
\mathrm{O}_{4} & 1 \mathrm{~g} / \mathrm{l} \\
\mathrm{c}^{\mathrm{c}} \mathrm{C}-\mathrm{YE} & 7.5\end{array}$ \\
\hline
\end{tabular}

\section{Effect of SCSM composition on VHG ethanol production}

In addition to SCSM, the VHG ethanol fermentation was performed in a series of incomplete SCSM that lacked some components (Table 1). The basic modified SCSM (mSCSM) had no added trace elements, due to their potential presence in the SCS. Additional changes included the omission of one or more of the inorganic nutrients (-IN), peptone (-P) and YE (-YE). Cultures were otherwise grown as above (up to $72 \mathrm{~h}$ at $30^{\circ} \mathrm{C}$ under an oxygen limited condition with $\mathrm{CO}_{2}$ release and shaking at $100 \mathrm{rpm}$ ) to determine the effects of the supplements on the ethanol production level.

\section{Preparation of A-YE and SE-YE}

Spent brewer's yeast, obtained from the Pathumthani Brewery Co., Ltd. (Pathumthani, Thailand), was precipitated by centrifugation using a screw decanter continuous centrifuge (Kansai centrifugal separator manufacturing Co., Ltd., Fukushima, Osaka, Japan) at room temperature and $8838 \mathrm{~g}$, and washed with $1 \mathrm{M} \mathrm{NaOH}$ and then distilled water prior to being stored at $-20^{\circ} \mathrm{C}$ until used. The washed spent brewer's yeast cells (300 g) were then suspended in distilled water (final $500 \mathrm{ml}$ ). For the A-YE, the cell suspension was incubated at $50^{\circ} \mathrm{C}$ for $24 \mathrm{~h}$, while for the SE-YE the cell suspension was treated in a high-pressure reactor (Parr Instrument Co., USA) at $200^{\circ} \mathrm{C}$ for $20 \mathrm{~min}^{12}$. In both cases the post-treatment suspension was centrifuged $\left(4^{\circ} \mathrm{C}, 11305 \mathrm{~g}, 10 \mathrm{~min}\right)$ and the resultant supernatant was spray-dried and analysed for total nitrogen ${ }^{13}$, vitamins (Pantothenic acid $^{11}$, Biotin ${ }^{14}$, Thiamine ${ }^{15}$, and Pyridoxine ${ }^{15}$ )
Table 2 Some inorganic nutrient and trace element contents in the SCS solution.

\begin{tabular}{lr}
\hline Composition & $\mathrm{mg} / \mathrm{kg}$ \\
\hline Copper (Cu) & - \\
Calcium (Ca) & 6.79 \\
Zinc (Zn) & 0.07 \\
Manganese (Mn) & 0.07 \\
Potassium (K) & 94.51 \\
Phosphorus (P) & 15.06 \\
Nitrogen (N) & 183 \\
Magnesium (Mg) & 5.68 \\
\hline
\end{tabular}

" Limit of detection $0.36 \mathrm{mg} / \mathrm{kg}$.

and amino acid contents commercially at ALS Laboratory Group Thailand Co., Ltd.

\section{Comparison between commercial YE (C-YE), A-YE and SE-YE supplements on VHG ethanol production}

The VHG ethanol fermentation was performed using the $\operatorname{mSCSM}(-\mathrm{P})$ medium (Table 1) except the C-YE was, where stated, replaced with either A-YE or SEYE to give the same level of nitrogen and protein content as C-YE at $7.5 \mathrm{~g} / \mathrm{l}$. The C-YE (Bio Springer Company, France) used in this study was prepared by autolysis.

\section{Analytical and statistical procedures}

Yeast cell number was determined by haemocytometer under light microscopy. Ethanol concentration was analysed by gas chromatography ${ }^{8}$. Results are presented as the mean \pm standard deviation (SD) from the indicated number of independent replications. The statistical significance between different means was tested using Duncan's new multiple range test (DMRT), performed using the SPSS 16.0. Significance was accepted at the $p<0.05$ level.

\section{RESULTS AND DISCUSSION}

\section{Production of the SCS solution (280 $\mathrm{g}$ reducing sugar/1)}

The SCS solution, as a clear syrup containing $280 \mathrm{~g} / 1$ reducing sugar was obtained when cassava starch (15 g) suspended in distilled water $(50 \mathrm{ml})$ was sequentially liquefied and saccharified by 26.39 AAU/g $\alpha$-amylase and 16.45 TGAU/g glucoamylase (data not shown), respectively. The contents of some of the trace elements and inorganic nutrients in the clear SCS syrup are shown in Table 2. 
Table 3 Ethanol production by $S$. cerevisiae $\mathrm{G} 2-3-2$ in oEPM medium.

\begin{tabular}{lccc}
\hline $\begin{array}{l}\text { Time } \\
(\mathrm{h})\end{array}$ & $\begin{array}{c}\text { Concentration } \\
(\mathrm{g} / \mathrm{l})\end{array}$ & $\begin{array}{c}\text { Yield } \\
(\mathrm{g} / \mathrm{g})\end{array}$ & $\begin{array}{c}\text { Productivity } \\
(\mathrm{g} / \mathrm{l} / \mathrm{h})\end{array}$ \\
\hline 24 & $92.76^{\mathrm{B}} \pm 1.53$ & 0.33 & 3.87 \\
48 & $106.73^{\mathrm{A}} \pm 1.26$ & 0.38 & 2.22 \\
72 & $108.96^{\mathrm{A}} \pm 0.21$ & 0.39 & 1.51 \\
96 & $105.90^{\mathrm{A}} \pm 0.97$ & 0.38 & 1.10 \\
\hline
\end{tabular}

" Data are displayed as the mean \pm SD and derived from triplicate experiments. Means followed by a different letter are significantly different, $p<0.05$, by one-way ANOVA and Duncan's multiple range test.
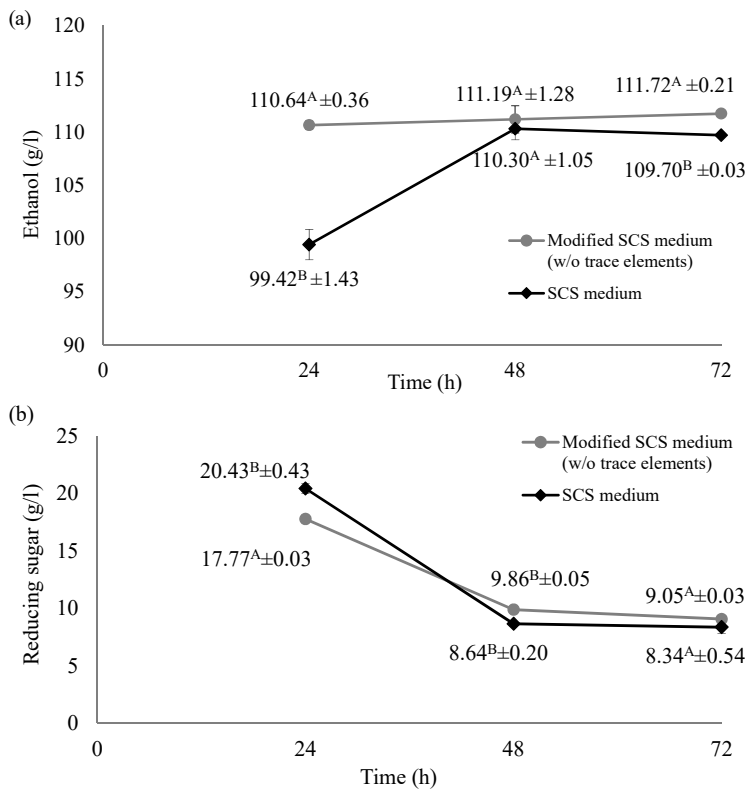

Fig. 1 (a) Ethanol production and (b) residual reducing sugar level in the SCSM (inorganic nutrients, YE, peptone and trace elements) and MSCSM (without the trace elements). The data are displayed as the mean \pm SD and derived from triplicate experiments. Means with a different letter are significantly different, $p<0.05$, oneway ANOVA and DMRT.

\section{Effect of the SCS medium composition on VHG ethanol production}

Under the evaluated conditions, S. cerevisiae G23-2 produced a maximum ethanol concentration $(108.96 \mathrm{~g} / \mathrm{l})$ at $72 \mathrm{~h}$, with an ethanol yield and productivity of $0.39 \mathrm{~g} / \mathrm{g}$ reducing sugar and $1.51 \mathrm{~g} / \mathrm{l} / \mathrm{h}$, respectively, in the oEPM medium. The ethanol production rate decreased with increasing fermentation time, while the ethanol concentration in the ferment increased with fermentation time up to $72 \mathrm{~h}$
Table 4 Effect of medium composition in modified SCS medium (without trace elements) on VHG ethanol production.

\begin{tabular}{lcccc}
\hline \multirow{2}{*}{$\begin{array}{l}\text { Time } \\
\text { (h) }\end{array}$} & \multicolumn{4}{c}{ Ethanol concentration* (g/l) in mSCSM } \\
\cline { 2 - 5 } & YE+P+IN & YE+P (-IN) & YE (-P)+IN & P (-YE)+IN \\
\hline 24 & $110.6^{\mathrm{A}} \pm 0.4$ & $100.2^{\mathrm{B}} \pm 0.4$ & $113.1^{\mathrm{A}} \pm 0.9$ & $107.2^{\mathrm{B}} \pm 1.3$ \\
48 & $111.2^{\mathrm{A}} \pm 1.3$ & $110.8^{\mathrm{A}_{ \pm}} 1.8$ & $113.2^{\mathrm{A}} \pm 0.3$ & $109.5^{\mathrm{C}} \pm 0.2$ \\
72 & $111.7^{\mathrm{B}} \pm 0.2$ & $109.1^{\mathrm{C}} \pm 1.3$ & ND & ND \\
\hline * & Data are displayed as the mean \pm SD and derived from \\
triplicate experiments. Means followed by a different \\
letter are significantly different ( $p<0.05$ by one-way \\
ANOVA and Duncan's multiple range test). +, with \\
and -, without YE; C-YE 7.5 g/l; P 5 g/l; IN, inorganic \\
nutrients; ND, not determined.
\end{tabular}

(Table 3). In SCSM, a slightly higher maximum ethanol concentration (110.30 g/l) was obtained, and at a shorter fermentation time of $48 \mathrm{~h}$ (Fig. 1). Furthermore, a higher maximum ethanol concentration $(110.64 \mathrm{~g} / \mathrm{l})$ was obtained sooner (within $24 \mathrm{~h}$ ) in the mSCSM, that is when the SCSM was modified by removal of the trace elements supplement (Fig. 1). Hence the effect of the inorganic and complex nutrients (C-YE and peptone) on the VHG ethanol production in the mSCSM was further determined.

When the inorganic nutrients were omitted, a similar maximum ethanol concentration $(110.76 \mathrm{~g} / \mathrm{l})$ was obtained but after a longer fermentation period $(48 \mathrm{~h})$. This likely reflects the insufficient levels of phosphate and magnesium ions in the SCS, as they are necessary for the growth and vitality of yeast, being involved in metabolic and bioenergetics pathways. Magnesium ions are required for the activity of several enzymes ${ }^{16}$. Whereas, removal of the peptone resulted in a slightly larger maximum ethanol concentration (113.14 g/l), which was still obtained within $24 \mathrm{~h}$. The omission of the YE, however, resulted in a decreased maximum ethanol concentration to $109.48 \mathrm{~g} / 1$ and was obtained at a slower rate, being obtained at $48 \mathrm{~h}$ (Table 4). That the mSCSM gave a lower ethanol level than the $\operatorname{mSCSM}(-\mathrm{P})$ might result from the higher ammonium content in the ferment. Excessive ammonium ions increase the production of higher alcohols, acetic acid and $\mathrm{H}_{2} \mathrm{~S}$, which have a negative effect on ethanol production ${ }^{1}$. From these results, mSCSM(-P) was selected for further investigation of the different YEs. 
Table 5 Comparison of the protein and nitrogen contents of the different yeast extracts.

\begin{tabular}{lcc}
\hline Type of YE & Protein content (\%) & Nitrogen content $(\%)^{*}$ \\
\hline C-YE & $72.83^{\mathrm{A}} \pm 0.70$ & $11.65^{\mathrm{A}} \pm 0.12$ \\
A-YE & $69.84^{\mathrm{B}} \pm 0.36$ & $11.13^{\mathrm{A}} \pm 0.12$ \\
SE-YE & $50.39^{\mathrm{C}} \pm 0.37$ & $8.06^{\mathrm{B}} \pm 0.06$ \\
\hline
\end{tabular}

* Data are displayed as the mean \pm SD and derived from triplicate experiments. Means followed by a different letter are significantly different $(p<0.05$, by one-way ANOVA and Duncan's multiple range test).

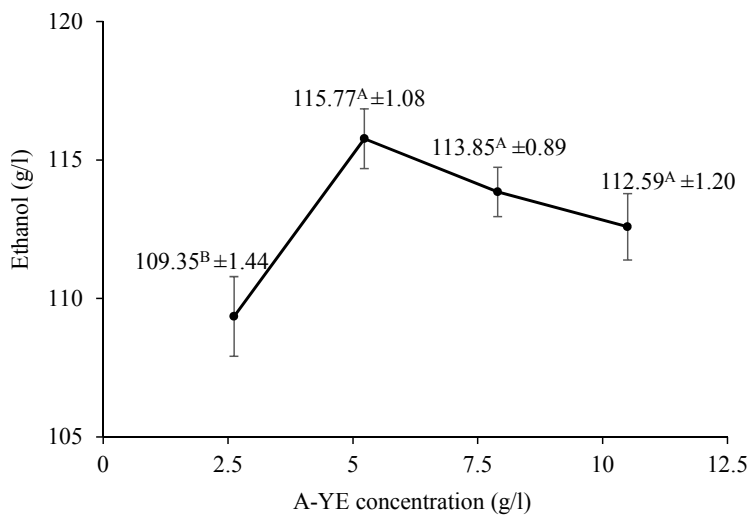

Fig. 2 Effect of the A-YE concentration on the ethanol production in mSCSM(-P) except supplemented with different concentrations of A-YE in place of C-YE. The data are displayed as the mean \pm SD and derived from triplicate experiments. Means with a different letter are significantly different $(p<0.05$, DMRT).

\section{Comparison of the A-YE and SE-YE characteristics}

The residual solid yield of SE-YE was 65\% lower than that obtained for A-YE, which reflects the larger extent of hydrolysis that occurred at the higher temperature in SE-YE production than in A-YE. Furthermore, the protein and nitrogen contents of the SE-YE were $17 \%$ and $38 \%$, respectively, lower than those of A-YE (Table 5). The protein and organic nitrogen in the SE-YE might have been degraded at the very high process temperature $\left(200^{\circ} \mathrm{C}\right)$ of the steam explosion. In contrast, the A-YE had very similar protein and nitrogen contents to the C-YE (Table 5), in accord with their similar production process (autolysis).

\section{Comparison of A-YE and SE-YE as supplements for VHG ethanol production}

Each VHG ethanol fermentation was performed in $\operatorname{mSCSM}(-\mathrm{P})$ containing the respective YE. For the
Table 6 Amino acid composition of the different yeast extracts (mg/100 g).

\begin{tabular}{lrrr}
\hline Amino acids & C-YE & A-YE* & SE-YE* \\
\hline Alanine & 5240 & 5210 & 5380 \\
Arginine & 7850 & 7750 & 4820 \\
Aspartic acid & 6980 & 6830 & 3160 \\
Cystine & 300 & 436 & 27 \\
Glutamic acid & 12600 & 6690 & 8170 \\
Glycine & 3100 & 3390 & 3030 \\
Histidine & 1340 & 1400 & 927 \\
Isoleucine & 3680 & 4110 & 2450 \\
Leucine & 5740 & 6290 & 3990 \\
Lysine & 5670 & 5610 & 2950 \\
Methionine & 1520 & 1620 & 966 \\
Phenylalanine & 3370 & 3740 & 2190 \\
Proline & 3190 & 3710 & 3140 \\
Serine & 4350 & 4310 & 3160 \\
Threonine & 3600 & 3690 & 2300 \\
Tryptophan & 699 & 781 & 293 \\
Tyrosine & 1450 & 3050 & 2470 \\
Valine & 4310 & 4790 & 3280 \\
\hline
\end{tabular}

" ALS Laboratory Group Thailand Co., Ltd.

Table 7 Vitamin contents $(\mathrm{mg} / 100 \mathrm{~g}$ ) in the different yeast extracts.

\begin{tabular}{lcc}
\hline Vitamin & YE & Vitamin content $^{*}$,a \\
\hline Biotin & C-YE & $52.70^{\mathrm{b}}$ \\
& A-YE & $58.40^{\mathrm{b}}$ \\
& SE-YE & $56.70^{\mathrm{b}}$ \\
\hline Thiamine & C-YE & 2.19 \\
& A-YE & 12.40 \\
& SE-YE & 0.43 \\
\hline Pantothenic acid & C-YE & 9.72 \\
& A-YE & 7.71 \\
\hline Pyridoxine & SE-YE & 0.57 \\
& C-YE & 1.12 \\
& A-YE & 0.90 \\
& SE-YE & ND \\
\hline
\end{tabular}

" ALS Laboratory Group Thailand Co., Ltd.;

${ }^{a}$ Limit of detection is $0.003 \mathrm{mg} / 100 \mathrm{~g}$;

${ }^{\mathrm{b}}$ the concentration unit is $\mu \mathrm{g} / 100 \mathrm{~g}$; ND, not determined.

medium with C-YE, the maximum ethanol concentration $(113.14 \mathrm{~g} / \mathrm{l})$ was produced after $24 \mathrm{~h}$ when the media was supplemented with C-YE at $7.5 \mathrm{~g} / 1$ (protein and nitrogen contents of $0.55 \%$ and $0.09 \%$ (w/v), respectively). The replacement of the C-YE with the low-cost A-YE or SE-YE was then evaluated at the same protein and nitrogen level. Supplementation with A-YE $(7.9 \mathrm{~g} / \mathrm{l})$ gave essentially the 
same maximum ethanol concentration (113.85 g/l) as that obtained with the C-YE, while SE-YE gave a lower level of ethanol $(107.81 \mathrm{~g} / \mathrm{l})$. Thus the AYE was selected for optimizing the amount of YE supplement by evaluation at $2.62-10.5 \mathrm{~g} / \mathrm{l}$. Under these conditions, the mSCSM(-P) supplemented with $5.23 \mathrm{~g} / \mathrm{l} \mathrm{A}-\mathrm{YE}$ gave a maximum ethanol concentration of $115.77 \mathrm{~g} / \mathrm{l}$ after $24 \mathrm{~h}$ of fermentation (Fig. 2).

Analysis of the amino acid content of the C-YE, A-YE and SE-YE revealed that the SE-YE contained a lower level of amino acids compared to A-YE, except for alanine and glutamic acid (Table 6). The amino acid content of YE is known to decrease with increasing temperature during the preparation process ${ }^{12}$. In addition, the higher level of some amino acids in A-YE might also be a result of several proteins produced in the autolysis process. Of note, the level of the thiamine, pantothenic acid and pyridoxine, which are important for growth and ethanol fermentation of yeast, were found at a markedly lower concentration in SE-YE than A-YE (Table 7). Of these, thiamine was also significantly lower in $\mathrm{C}-\mathrm{YE}$ than in A-YE, although still five-fold higher than in SE-YE and so still potentially limiting. This might account for the lower ethanol production by SE-YE. Deficiency of thiamine, pantothenic acid and pyridoxine results in a reduced yeast growth ${ }^{17}$. For example, pyruvate decarboxylase, which catalyses decarboxylation of pyruvate to acetaldehyde and $\mathrm{CO}_{2}$, requires thiamine ${ }^{18,19}$, while the synthesis of coenzyme $\mathrm{A}$ and acetyl-CoA requires pantothenic $\operatorname{acid}^{20}$.

\section{CONCLUSIONS}

The VHG ethanol production from SCS $(280 \mathrm{~g} / \mathrm{l}$ reducing sugar) by $S$. cerevisiae G2-3-2 required supplementation of the substrate with inorganic nutrients and YE. The YE prepared by cell autolysis (A-YE) was as effective as the more expensive C-YE, but the SE-YE gave a lower ethanol concentration in the ferment, perhaps reflecting the lower content of essential amino acids and vitamins in SE-YE. Thus the cost of ethanol formation by VHG fermentation of cassava could be made more commercially viable by using locally made A-YE in place of imported CYE.

Acknowledgements: The authors express sincere appreciation and thanks to the Thai Alcohol Public Company, Thailand for providing the $\alpha$-amylase and glucoamylase enzymes; Mrs Vasana Tolieng for her excellent assistance in facilitating and guiding the usage of the screw decanter continuous centrifuge; Dr Robert DJ Butcher for his assistance in English proofreading and valuable comments on the manuscript. This study was financially supported by the Thai Government budget (fiscal year 2016).

\section{REFERENCES}

1. Laopaiboon L, Nuanpeng S, Srinophakun P, Klanrit P, Laopaiboon P (2009) Ethanol production from sweet sorghum juice using very high gravity technology: Effect of carbon and nitrogen supplementations. Bioresour Technol 100, 4176-82.

2. Bayrock DP, Ingledew WM (2001) Application of multistage continuous fermentation for production of fuel alcohol by very-high-gravity fermentation technology. J Ind Microbiol Biotechnol 27, 87-93.

3. Thomas KC, Hynes SH, Ingledew WM (1996) Practical and theoretical considerations in the production of high concentrations of alcohol by fermentation. Process Biochem 31, 321-31.

4. Kawa-Rygielska J, Pietrzak W (2014) Ethanol fermentation of very high gravity (VHG) maize mashes by Saccharomyces cerevisiae with spent brewer's yeast supplementation. Biomass Bioenergy 60, 50-7.

5. Wang FQ, Gao CJ, Yang CY, Xu P (2007) Optimization of an ethanol production medium in very high gravity fermentation. Biotechnol Lett 29, 233-6.

6. D'Amore T, Panchal CJ, Russell I, Stewart GG (1988) Osmotic pressure effects and intracellular accumulation of ethanol in yeast during fermentation. $J$ Ind Microbiol 2, 365-72.

7. Bafrncová P, Smogrovicová D, Sláviková I, Pátková J, Dömény Z (1999) Improvement of very high gravity ethanol fermentation by media supplementation using Saccharomyces cerevisiae. Biotechnol Lett 21, 337-41.

8. Hoondee P, Tolieng V, Tanasupawat S, Kitpreechavanich V, Akaracharanya A (2014) Very high gravity ethanol fermentation by the newly isolated osmotolerant Saccharomyces cerevisiae isolate G2-3-2. Chiang Mai J Sci 41, 1-16.

9. Somogyi M (1952) Notes on sugar determination. $J$ Biol Chem 195, 19-23.

10. Association of Official Analytical Chemists (2005) Official Methods of Analysis, 18 edn, AOAC International.

11. Association of Official Analytical Chemists (2012) Official Methods of Analysis, 19 edn, AOAC International.

12. Lamoolphak W, Goto M, Sasaki M, Suphantharika M, Muangnapoh C, Prommuag C, Shotipruk A (2006) Hydrothermal decomposition of yeast cells for production of proteins and amino acids. $J$ Hazard Mater 137, 1643-8.

13. Kjeldahl J (1883) Neue methode zur bestimmung des stickstoffs in organischen Körpern. Fresenius Zeitschrift Anal Chemie 22, 366-82. 
14. Angyal G (1996) US Food and Drug Administration, Methods for the Microbiological Analysis of Selected Nutrients, AOAC International.

15. Arella F, Lahély S, Bourguignon JB, Hasselmann C (1996) Liquid chromatographic determination of vitamins B1 and B2 in foods a collaborative study. Food Chem 56, 81-6.

16. Udeh HO, Kgatla TE (2013) Role of magnesium ions on yeast performance during very high gravity fermentation. J Brew Distilling 4, 19-45.

17. Nordstrom K (1962) Formation of ethyl acetate in fermentation with brewer's yeast III. JIB 68 , 398-407.

18. Dixon M, Webb EG (1964) Enzymes, Academic Press, USA.

19. Pronk JT, Ydesteensmay H, Van Dijken JP (1996) Pyruvate Metabolism in Saccharomyces cerevisiae Yeast, Wiley, USA.

20. Gutierrez LE (1993) Effect of some vitamins and micronutrient deficiencies on the production of higher alcohols by Saccharomyces cerevisiae. Scientia Agricola 50, 484-9. 